\title{
Cell Phone Use While Driving: A Pattern of Risk in Young Novice Drivers
}

\author{
Elizabeth A Walshe, $\mathrm{PhD}^{12}$, Flaura K Winston, $\mathrm{MD}, \mathrm{PhD}^{2}$, Laura M Betancourt ${ }^{3}$, Kristin Arena ${ }^{3}$ and Daniel \\ Romer, $\mathrm{PhD}^{1}$ \\ ${ }^{1}$ Annenberg Public Policy Center, University of Pennsylvania, Philadelphia, PA, USA \\ ${ }^{2}$ Center for Injury Research and Prevention, The Children's Hospital of Philadelphia, Philadelphia, PA, USA \\ ${ }^{3}$ Children's Hospital of Philadelphia, Philadelphia, PA, USA
}

Submission: December 01, 2017; Published: May 15, 2018

*Corresponding author: Elizabeth A Walshe, PhD, Annenberg Public Policy Center, University of Pennsylvania, 202 S 36th Street, Philadelphia, Pennsylvania, 19104, USA, Tel: 215-898-7020; Fax: 215-573-7116; Email: elizabeth.walshe@appc.upenn.edu

\begin{abstract}
Texting while driving is becoming more prevalent among young novice drivers, and has been specifically targeted as a risk factor for teen motor vehicle crashes. However, educational campaigns and prohibitive legislation for texting while driving have had minimal success. This may be because drivers who text while driving also take other risks that contribute to crashes (e.g. ignore speed limits). To assess this possibility in a community sample of young drivers, we used a modified version of the commonly used Driving Behavior Questionnaire (DBQ), and included two items to identify cell phone use while driving (calling and texting). Cell phone use correlated with prior citations and crashes, and loaded highly with other intentional violations (showing good construct validity) in an exploratory factor analysis. This suggests a pattern of risky driving behavior, of which texting is only one manifestation. Future research should examine the unique contribution of cell phone use as a risk for crashes in young drivers.
\end{abstract}

Keywords: Driving; Novice drivers; Cell phones; Texting; Risk behavior; Motor vehicle Crashes

\section{Introduction}

Adolescents appear to be particularly vulnerable to distraction-related crashes and growing research suggests that cell phone use while driving--which increases a driver's crash risk four-fold--is only becoming more prevalent $[1,2]$. With mounting public concern, texting while driving (TWD) has been targeted as a public health risk, yet educational campaigns and prohibitive legislation have had minimal success [3]. One possible reason for this is that TWD is only one of many risky behaviors that young drivers may perform: e.g. those who engage in TWD may also take other intentional risks (e.g. ignoring speed limits) that lead them to crash. More recent work is exploring these patterns of behavior and the individual traits of drivers which may indicate higher risk $[4,5]$.

The Driving Behavior Questionnaire (DBQ) [6] is one of the most commonly used measures of risky driving behavior that has been validated across numerous countries and populations, showing success in predicting self-reported crashes [7]. However, it was developed in the late 1980 s before the widespread use of cell phone technology. While modified versions of the DBQ have been developed, few have included items of cell phone use among young drivers [8,9]. Here, we measured risky driving behavior with a modified version of the DBQ, and two additional items of cell phone use while driving. We used factor analysis to determine whether cell phone use represents a unique source of driving risk behavior (reflected in self-reported citations and crashes) in a sample of young novice drivers.

\section{Methods}

\section{Sample}

One hundred and eighteen young adults were recruited from the final wave of the longitudinal Philadelphia Trajectory Study (PTS) [10] to complete a follow-up survey of driving (approved by the IRB of the Children's Hospital of Philadelphia). The PTS enrolled 387 youth aged 10 to 12 years in 2007 and retained 290 at ages 18 to 19 years. The current analysis was conducted with 84 participants who held a driver's license and completed the questionnaire. The mean age was 18.93 years $(\mathrm{SD}=.77$; range: $18-$ 20.6 years) and $53.5 \%$ were female. This subsample of drivers did not differ substantially from the demographic profile of the wider PTS sample (when compared to a second random subsample of 84 participants).

\section{Measures}

A subset of items was adapted from the DBQ to examine selfreported driving experience (e.g. type of license, number of years 
driving), history of crashes and ticketed violations (citations) [6]. Crash history (ever, and in the past 12 months) and prior citations (ever) were coded from $0=$ none, $1=$ one, $2=$ more than one. The two crash history items were recoded into a single binary variable (ever crash: $0=$ never, $1=$ crash). Nine high-risk ("definite risk to others") items were selected from the DBQ to measure engagement in risky driving behaviors. These driving behavior

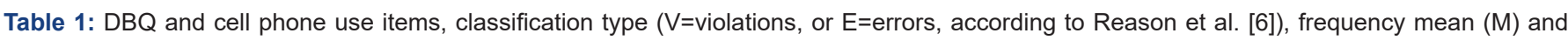
standard deviation $(\mathrm{SD})$ values. Note: $\mathrm{DBQ}=$ Driving Behavior Questionnaire.

\begin{tabular}{|c|c|c|c|c|}
\hline Item & Driving Questionnaire Items & Type & M & SD \\
\hline \multicolumn{5}{|c|}{$\begin{array}{l}\text { Here are some common things that drivers do. Please indicate how often, if at all, each of them has } \\
\text { happened to you while you were driving: }\end{array}$} \\
\hline 1 & Ignored speed limits late at night or early in the morning? & $\mathrm{V}$ & 2.42 & 1.44 \\
\hline 2 & $\begin{array}{c}\text { Drove close to a car ahead of you or flashed your lights as a signal to go faster or get out } \\
\text { of your way? }\end{array}$ & $\mathrm{V}$ & 1.54 & 0.99 \\
\hline 3 & Became impatient with a slow driver in the left passing lane and passed on the right? & $\mathrm{V}$ & 2.3 & 1.33 \\
\hline 4 & $\begin{array}{l}\text { Drove with only "half an eye" on the road while looking at a map or using the controls in } \\
\text { the car? }\end{array}$ & $\mathrm{E}$ & 2.12 & 1.19 \\
\hline 5 & Took a chance on going through an intersection when the light turned red? & $\mathrm{V}$ & 1.62 & 0.92 \\
\hline 6 & Drove after consuming alcohol? & $\mathrm{V}$ & 1.08 & 0.28 \\
\hline 7 & Misjudged the speed of an oncoming vehicle when passing a car? & E & 1.43 & 0.73 \\
\hline 8 & Failed to check your mirrors before pulling out of a parking spot or changing lanes? & E & 1.55 & 0.72 \\
\hline 9 & Failed to notice someone stepping out from behind a bus or parked vehicle? & $\mathrm{E}$ & 1.27 & 0.52 \\
\hline 10 & Talked on a cell phone while driving? & - & 2.23 & 1.25 \\
\hline 11 & Answered a text message while driving? & - & 2.11 & 1.25 \\
\hline
\end{tabular}

\section{Analysis}

Statistical analyses were conducted using IBM SPSS Statistics 24 and Mplus 8. We conducted an exploratory factor analysis of the 11 risky driving items, using a principal axis extraction and a varimax rotation (with Kaiser normalization). We then subjected the solution to a confirmatory factor analysis (CFA). Correlation coefficients between the risky driving items and prior crashes and citations were calculated.

\section{Results}

These young drivers had an average of 2 years driving experience ( $S D=1.2)$. Twenty-five (29.8\%) reported being in at least one crash as a driver, and $13(15.5 \%)$ reported that they had previously received a citation. Approximately 3 out of 5 participants reported that they engaged in CWD (60.7\%) and TWD (58.3\%). The cell phone items were interrelated with many of the DBQ items. items were selected from the two most commonly reported DBQ latent constructs: deliberate violations (V: 5 items) and driving errors (E: 4 items) [6]. See Table 1. Two additional items asked about texting (TWD) and talking on a cell while driving (CWD). Participants indicated how often they engaged in each behavior using a 6 -point scale $(1=$ never to $6=$ =nearly all the time) (Table 1$)$.
Exploratory factor analysis revealed three underlying factors with an eigenvalue $>1$. The first factor (eigenvalue=3.84) explained $34.9 \%$ of the variance, and consisted mostly of violations (4) the cell phone items (2), plus one error item. CWD and TWD loaded highly on this factor. TWD and two other items were related to crash history, and all but one item correlated positively with prior citations (see Table 2). Thus, this factor appears to represent intentional violations. A second factor (eigenvalue=1.60) consisting of 2 error items and 1 violation accounted for $14.5 \%$ of the variance (Error factor). The third factor (eigenvalue=1.05) consisted of only 1 error (item 9) and explained 9.6\% of the variance. The CFA confirmed the two factor model with a satisfactory fit: comparative fit index $(\mathrm{CFI})=.97$, the Tucker-Lewis fit index (TLI)=.96, and root mean square error of approximation (RMSEA) $=.08$. There was also a significant positive correlation between the two factors: $r=0.562, p<.001$ (Table 2).

Table 2: CFA standardized item loadings on the Violation and Error factors (all $p<.001$ ), and correlation coefficients ( $r$ ) with self-reported crashes

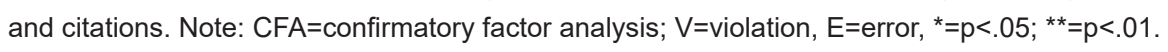

\begin{tabular}{|c|c|c|c|c|c|}
\hline Item & Driving Survey Item & $\begin{array}{l}\text { Violation } \\
\text { Factor }\end{array}$ & $\begin{array}{l}\text { Error } \\
\text { Factor }\end{array}$ & $\begin{array}{c}\text { Citation } \\
\mathbf{r}\end{array}$ & $\begin{array}{c}\text { Crash } \\
\mathbf{r}\end{array}$ \\
\hline 1 & Ignored speed limits late at night or early in the morning? & 0.678 & & 0.146 & -0.008 \\
\hline 2 & $\begin{array}{l}\text { Drove close to a car ahead of you or flashed your lights as a signal to } \\
\text { go faster or get out of your way? }\end{array}$ & 0.724 & & $.292^{* *}$ & -0.063 \\
\hline 3 & $\begin{array}{l}\text { Became impatient with a slow driver in the left passing lane and } \\
\text { passed on the right? }\end{array}$ & 0.743 & & $.269^{*}$ & $.227^{*}$ \\
\hline
\end{tabular}




\section{Academic Journal of Pediatrics \& Neonatology}

\begin{tabular}{|c|c|c|c|c|c|}
\hline 4 & $\begin{array}{c}\text { Drove with only "half an eye" on the road while looking at a map or } \\
\text { using the controls in the car? }\end{array}$ & 0.815 & & $.342^{* *}$ & $.221^{*}$ \\
\hline 6 & Drove after consuming alcohol? & 0.627 & & 0.06 & 0.181 \\
\hline 10 & Talked on a cell phone while driving? & 0.758 & & $.311^{* *}$ & 0.197 \\
\hline 11 & Answered a text message while driving? & 0.792 & & $.227^{*}$ & $.237^{*}$ \\
\hline 5 & $\begin{array}{c}\text { Took a chance on going through an intersection when the light } \\
\text { turned red? }\end{array}$ & & 0.623 & $.250^{*}$ & 0.015 \\
\hline 7 & Misjudged the speed of an oncoming vehicle when passing a car? & & 0.802 & 0.108 & 0.01 \\
\hline 8 & $\begin{array}{c}\text { Failed to check your mirrors before pulling out of a parking spot or } \\
\text { changing lanes? }\end{array}$ & & 0.471 & -0.097 & $-.244^{*}$ \\
\hline 9 & $\begin{array}{l}\text { Failed to notice someone stepping out from behind a bus or parked } \\
\text { vehicle? }\end{array}$ & & & 0.03 & -0.193 \\
\hline
\end{tabular}

\section{Conclusions}

Those who frequently engage in CWD and TWD were more likely to be involved in a crash, have prior citations, and commit other intentional driving violations-jeopardizing the safety of all on the road. Thus, TWD and CWD appear to be behaviors indicative of a broader pattern of intentional risk-taking while driving-in line with other work [4,5]. This pattern may be attributable to underlying characteristics or traits of young drivers that predispose to risky driving. Thus, it will be critical to determine if cell phone use is just one manifestation of such traits, or a unique risk factor for crashes. Although our subsample was representative of the wider PTS study, these findings should be replicated in a larger sample with prospective assessments. Nevertheless, these findings suggest that interventions might be more effective if they promoted safe driving behavior more broadly, rather than attempting to ban isolated risk behaviors. Future research should also focus on identifying the individual characteristics of adolescent drivers prone to engaging in risky driving behaviors, so that we may predict those at risk.

\section{Acknowledgement}

The authors acknowledge and thank Joan Giannetta for her contribution to the study, and Catherine McDonald for feedback on the draft manuscript. This research was supported by a grant from the U. S. National Institute on Drug Abuse (R01 DA 18913) and the Center for Injury Research and Prevention at the Children's Hospital of Philadelphia.

\section{Competing Interests}

The authors have no competing interests to declare in relation to this work at this time.

\section{Ethical Approval}

Ethical approval was granted by the Children's Hospital of Philadelphia (CHOP IRB\#: 12-009665).

\section{References}

1 Ige J, Banstola A, Pilkington P (2016) Mobile phone use while driving: underestimation of a global threat. Journal of Transport \& Health 3(1): 4-8.

2 McEvoy SP, Stevenson MR, McCartt AT, Woodward M, Haworth C, et al. (2005) Role of mobile phones in motor vehicle crashes resulting in hospital attendance: a case-crossover study. BMJ 331(7514): 428.

3 McCartt AT, Kidd DG, Teoh ER (2014) Driver cellphone and texting bans in the United States: Evidence of effectiveness. Ann Adv Automot Med 58: 99-114.

4 Romer D, Lee Y, McDonald CC, Winston FK (2014) Adolescence, attention allocation, and driving safety. J Adolesc Health 54(5 Suppl): S6-S15.

5 Cook JL, Jones RM (2011) Texting and Accessing the Web While Driving: Traffic Citations and Crashes Among Young Adult Drivers. Traffic Inj Prev 12(6): 545-549.

6 Reason J, Manstead A, Stradling S, Baxter J, Campbell K (1990) Errors and violations on the roads: a real distinction? Ergonomics 33(10-11): 1315-1332.

7 de Winter JCF, Dodou D, Stanton NA (2015) A Quarter of a Century on the DBQ: Some supplementary notes on its validity with regard to accidents. Ergonomics 58(10): 1745-1769.

8 Freeman J, Davey J, Wishart D (2007) A study of Contemporary Modifications to the Manchester Drivers Behaviour Questionnaire for Organizational Fleet Settings. Proceeding 3rd International Driver Behaviour and Training Conference, Ireland.

9 Harrison W (2009) Reliability of the Driver Behavior Questionnaire in a Sample of Novice Drivers. Proceedings of the Australian Road Safety Research, Policing and Education Conference, New South Wales, Sydney.

10 Romer D, Betancourt L, Giannetta JM, Brodsky NL, Farah M, et al. (2009) Executive cognitive functions and impulsivity as correlates of risk taking and problem behavior in preadolescents. Neuropsychologia 47(13): 2916-2926. 


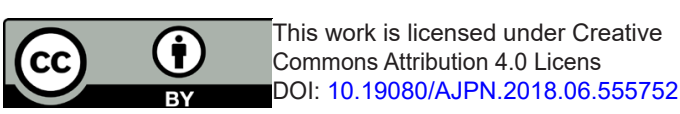

\section{Your next submission with Juniper Publishers will reach you the below assets}

- Quality Editorial service

- Swift Peer Review

- Reprints availability

- E-prints Service

- Manuscript Podcast for convenient understanding

- Global attainment for your research

- Manuscript accessibility in different formats

( Pdf, E-pub, Full Text, Audio)

- Unceasing customer service

Track the below URL for one-step submission https://juniperpublishers.com/online-submission.php 